\title{
Physicochemical and Thermal Characterization of Dura Palm Kernel Powder as a Load for Polymers: Case of Polyvinyl Chloride
}

\author{
Rolland Djomi' ${ }^{1}$, Lucien Jean Raymond Meva'a ${ }^{1}$, Jean Nganhou${ }^{1}$, Gérard Mbobda ${ }^{1}$, \\ Abel Emmanuel Njom1, Yves Didier Modtegue Bampel ${ }^{2}$, Jean-Bosco Saha Tchinda ${ }^{2 *}$ \\ ${ }^{1}$ Civil and Mechanical Engineering Laboratory, National Advanced School of Engineering, University of Yaounde I, Yaounde, \\ Cameroon \\ ${ }^{2}$ Research Unit for Macromolecular Chemistry, Applied Inorganic Chemistry Laboratory, Faculty of Science, University of \\ Yaounde I, Yaounde, Cameroon \\ Email: *saha_jb@yahoo.fr
}

How to cite this paper: Djomi, R., Meva'a, L.J.R., Nganhou, J., Mbobda, G., Njom, A.E., Bampel, Y.D.M. and Tchinda, J.-B.S. (2018) Physicochemical and Thermal Characterization of Dura Palm Kernel Powder as a Load for Polymers: Case of Polyvinyl Chloride. Journal of Materials Science and Chemical Engineering, 6, 1-18. https://doi.org/10.4236/msce.2018.66001

Received: May 10, 2018

Accepted: June 18, 2018

Published: June 21, 2018

Copyright (c) 2018 by authors and Scientific Research Publishing Inc. This work is licensed under the Creative Commons Attribution International License (CC BY 4.0).

http://creativecommons.org/licenses/by/4.0/

\begin{abstract}
This work presents the physical and thermal characterization of the dura palm kernel powder of Cameroon for their use as fillers for polymers composites. The powders of palm kernel were obtained using a percussion grinder mill with an industrial microniser which allowed obtaining a powder less than 50 $\mu \mathrm{m}$ with an apparent density between $0,505 \leq \rho \leq 0,680 \mathrm{~g} / \mathrm{cm}^{3}$ at 1.56 of relative humidity. The infrared of the powder of palm kernel shows the presence of phenols groups with a large band around $3341 \mathrm{~cm}^{-1},-\mathrm{C}-\mathrm{H}$ at 2917.02 $\mathrm{cm}^{-1}$ and $-\mathrm{C}-\mathrm{O}$ at $1040 \mathrm{~cm}^{-1}$ as the main peaks. The polyvinyl chloride of infrared obtained shows the presence of $-\mathrm{C}-\mathrm{Cl},-\mathrm{CH}_{2}$ and $\mathrm{CH}$ as the mains peaks. The infrared of $12.5 \%$ of palm kernel powder with polyvinyl chloride shows an increase of the $\mathrm{CH}_{2}$ and $\mathrm{CH}$ bonds and a decrease of the - $\mathrm{OH}$ bonds. Thermogravimetric analysis and differential scanning calorimetric analysis of powders, polyvinyl chloride and mixture showed that the mixing powders are intermediate between the polyvinyl chloride and palm kernel powder. The powder decreased the phase temperatures of the mixture from $98.58^{\circ} \mathrm{C}$ to $95^{\circ} \mathrm{C}$ for the glass transition temperature and from $515^{\circ} \mathrm{C}$ to $459^{\circ} \mathrm{C}$ for the crystallization temperature. The thermogravimetric curves of palm kernel powder and polyvinyl chloride have showed that these materials lose their different masses in three different phases, and the one of composite (mixture of polyvinyl chloride with $12.5 \%$ of palm kernel powder) in two different phases.
\end{abstract}

\section{Keywords}

Dura Palm Kernel Shell, Load for Polymers, Thermogravimetric Analysis, DSC 


\section{Introduction}

Polyvinyl chloride (PVC) is one of the most important plastics used in the world today. They are mostly found in the packaging, electricity, electronics, electromechanical and building sectors [1]. Plastic offers a very great advantage especially in the possibility of its mixture with many other materials at the time of its manufacture [1] [2]. This feature makes the plastic material a financially accessible material for all. Thus, plastic production industries use carbides, glass fibers, carbon fibers [3] [4] [5], especially calcium carbides, as a filler to soften the costs of plastics [3]. Calcium carbide is a mineral material so they are found in large quantities and cheaper on the market. The major disadvantage of such plastic is that they are not biodegradable. Given their importance in the society, the need to replace them either in the form of a load or a form of reinforcement to facilitate its degradation at the end of its life is important. That's why since the 1980s, researchers have been trying to study the possibilities of incorporating plants into polymers during the manufacture of plastics, hence the name Wood Plastic Composites (WPC). In this way, several tests have been successful in the use of talc mineral [6], wood [7] [8], cactus [9], date palm fiber [10] in the form of fibers. The most striking results are the easy formatting (packaging, electricity, electronics...), the lightness of the plastic material (manufacturing, aeronautics...), and treatment (buildings...), next to other properties that are no longer to enumerate [11]. The advantages of the reinforced synthetic polymers with natural fibers are many such as: availability, low costs and abundance of natural fibers [12]. The reinforced plastics material obtained are inexpensive, renewable and nontoxic [5]. The characteristics of different natural fibers have been already described in literature except the one of palm kernel shell [13]. Apart from the charges mentioned above, we note that dura palm kernel powders can also be used as vegetable filler.

The palm kernel shell dura comes from palm oil, plant of the family ARECACEAE (palmae) of its scientific name Elaeis guinensis Jacq, referenced by comparison to the botanical collection of TAMAKI MARUHASHI of the national herbarium of Cameroon. This variety of palm oil is less exploited because of its low yield of oils that is the peculiarity of its exploitation [14]. They are found in very large quantities and in more than half of the Cameroon territory, but not maintained. Palm kernel husks represent the part of this least used plant (if so rarely for cooking) and are considered as harmful waste. Like its palm, they are found in very large quantities and much more thrown into nature.

It should be added that the palm oil sector in the world [15] in general and in Africa in particular is in the midst of valorization [16]. For example, Planet reports in "History of oil palm exploitation in Africa", GRAIN, 22 September 2014, in Guinea, palm oil exploitation is a source of stable employment, mitigates rural exodus and develops the local economic fabric. In West Africa, Benin, Côte d'Ivoire and Guinea, artisanal extraction of palm oil is done by the palm producer. Revenues enable them to support themselves and reflect the 
wealth of a clan or family. In the Lower Congo River, local knowledge around the palm oil is a rich heritage to be valued also for the protection of biodiversity

[17]. In all these countries, the usefulness of palms is limited to oils. The hulls of palm kernel also remain in all these countries, the part of the tree which is not used [4].

Palm kernel husks have been investigated in its use as fuel for cupolas [15] and for the production of activated carbon [17]. The vegetable loads are in full success in its elaboration [18].

Palm kernel shells are available not only in Cameroon, but also in abundance in Africa, the Mediterranean and in Southeast Asia [15]. They are an integral part of the list of oil palm pests [14]. The exploitation of palm kernel husks as an industrial load for polymers economically and socially leads to the valorization of the oil palm agricultural sector and the creation of new enterprises, in terms of the environment, the safeguarding of the ecosystem and scientifically, additional knowledge in the field of plant loads for the development of plastics.

The present study aims to set up a practical, experimental methodology to transformed nut shells into powder. Characterize the powder obtained and then use it as fillers for polymers in the production of plastics. It should also be noted that in the literature we have read so far no work of this kind on the use of hulls of palm kernels as fillers has been realized.

\section{Materials and Methods}

\subsection{Materials}

\subsubsection{The Raw Palm Kernels Shell of Dura}

The hulls of dura palm kernel were collected in Cameroon, in the littoral region and Moungo department. They were identified by comparison with the botanical collection of TAMAKI MARUHASHI $\mathrm{N}^{\circ} 103$ recorded in the national herbarium of Cameroon under $\mathrm{N}^{\circ} 47794 / \mathrm{HNC}$. These hulls come from the palmoil of the family ARECACEAE. Its scientific name is Elaeis guinensis Jacq. Determavit TADJOUTEU Fulbert HNC on 04/05/2018. The Figure 1 below shows the raw palm kernel shell of dura.

The raw palm kernel shells were previously dried until constant mass. The hulls were first crushed using a Retsch brand mill, type SN 100 of series No. 82508001 [19]. The machine was not able to crush them. We looked for the cause and we got that the hulls were very hard. Due to the hardness of the hulls, that was not crushed and ground crush by conventional machine, the design and manufacturing of an impact crusher in NASE Yaounde, with the characteristics listed in Table 1 was made.

\subsubsection{Characteristic Parameters of the Machine}

1) Thermogravimetric analysis

Thermogravimetric coupled with differential scanning calorimetry analysis was performed using a LINSEIS branded device connected to a computer with 
Table 1. Characteristic parameters of the machine used.

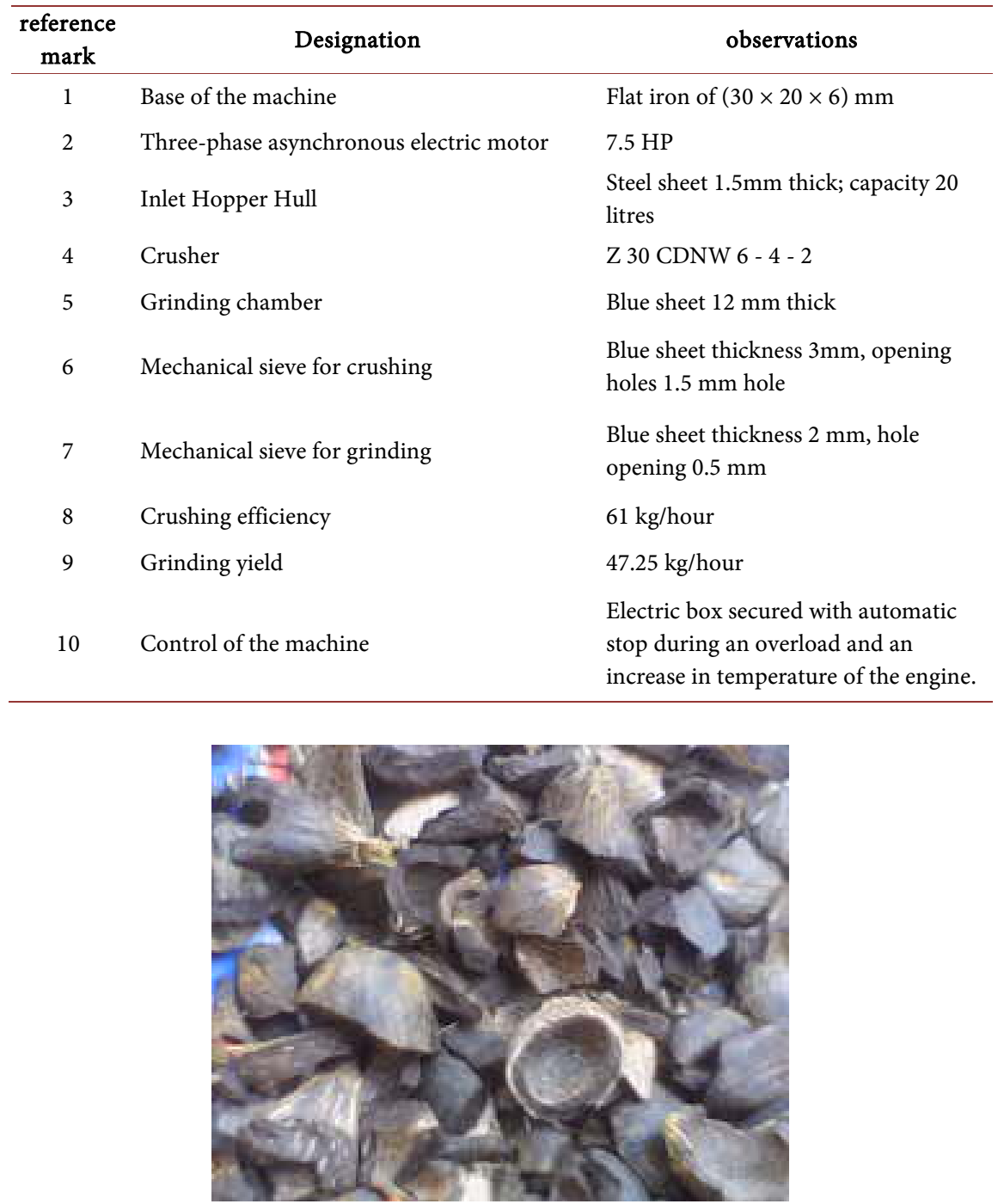

Figure 1. Raw palm kernel shell of dura.

embedded software for data acquisition. A $150 \mathrm{mg}$ capacity aluminum oxide crucibles were used with a; the speed of the measurement is variable and the combustion gases are nitrogen.

PVC that used was collected from the company DANSUK INDUSTRIAL CO., LTD under the name Vinova and batch number S6830 [20]. This PVC was used as given without any other purification.

2) Fourier transformed infrared analysis

Fourier transform infrared spectroscopy (FT-IR) was performed using the Nicolet iS5 IR spectrometer.

\subsection{Experimental Methods}

Processing of Raw Palm Kernel Shell into Palm Kernel Powder

Figure 2 shows the process of converting raw dried dura palm husks into powder. 


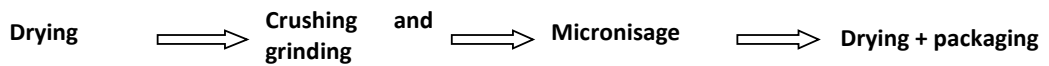

Figure 2. Synoptic diagram of the process of transformation of raw palm kernel shell into powder.

The dried palm kernel shells were poured into the hopper of the mill and are conveyed into the crushing chamber through the opening of the hatch. These are sucked by the centrifugal effect of the rotational movement of the mobile crusher which projects them on the walls of the grinding chamber. The centripetal force (Equation (1)) of the mobile crusher projects the hulls onto the stationary mills of the machine thus providing the necessary energy for their fragmentation.

$$
F=m \omega^{2} R
$$

The crushed hulls pass through the mesh size 1.5 mechanical sieves and are recovered. Subsequently, a sieve of 0.5 mesh is mounted in place of the previous to ensure the crushing of kernel shell previously crushed. The milled powder is transported to a micronizer which refines the powder and gives the desired grade $(50 \mu \mathrm{m})$. An oven heated to $103^{\circ} \mathrm{C}$ for 24 hours allows dehumidification. The appropriately dried powder is immediately stored in plastic bags.

\subsection{Characterization of Kernel Shell Powder}

\section{Physical Characterization}

\section{1) Density}

Apparent density: the method described by Ernesto de la Torre Chauvin in 2015 [21] was used to evaluate the apparent density (Equation (2)). The measure of apparent density consists to place an empty volumeter of capacity $1 \mathrm{~m}^{3}$ on the SEDITECH balance with a precision of $1 / 1000$ and tare. Fill the volumeter with palm kernel shell powder until $1 \mathrm{~m}^{3}$. For a volume $v_{i}$ of the powder, record the mass $m_{i}$. Determine the value of the mean and the standard deviation which represents the density $\rho_{v}$ of the micronized palm kernel shell powder.

$$
\rho_{v}=\frac{m_{i}}{v_{i}}
$$

where $m_{i}=$ mass of the powder and $v_{i}=$ volume of the powder.

Wetted density: the method described by Ernesto de la Torre Chauvin in 2015 [21] was used to evaluate the wetted density. It consists to take an empty flask of volume $V_{0}$ and weight the mass of the flask $\left(m_{0}\right)$. Add a mass $\mathrm{m}_{1}$ of water, and a mass $m_{2}$ of powder in the flask and let stand. Let all the mixture stand avoiding the formation of air bubbles in flask and note the mass $\left(m_{3}\right)$. The wet density $\rho_{m}$ is given by Equation (3). Calculate the average and the standard deviation of the records.

$$
\rho_{m}=\frac{\rho_{\text {water }}\left(m_{2}-m_{0}\right)}{\left(m_{2}-m_{0}\right)-\left(m_{3}-m_{1}\right)}
$$

\section{2) Granulometry of micronized palm kernel shell powders}


The particle size is sieved using an Afnor $50 \mu \mathrm{m}$ aperture calibrated sieve in order to ensure the wear of the microniser jaws.

\section{3) Moisture content of powder}

To evaluate the moisture contained of powder, we used the method described by Dietsch et al., 2014 [19]. Six ceramic crucibles containing the kernel nut shell powder whose mass $m_{h}$ was previously measured (with a mass of the crucible and the powder) were deposited for in an oven at $103^{\circ} \mathrm{C}$ until constant mass were obtained. The dried masses $\left(m_{d}\right)$ were recorded. The moisture content $(\mathrm{MC})$ of each sample is obtained by Equation (4) below.

The moisture content (MC) was calculated using the Equation (4) below.

$$
M C=\frac{m_{h}-m_{d}}{m_{d}} \times 100
$$

where $m_{h}$ is the wet mass of powder, and $m_{d}$ the anhydrous mass of the powder

\section{4) Thermal characterizations}

The thermal behavior of the shell powder is obtained by interpretation of the TG and DSC thermograms performed by the LINSEI instrument of the Physico-chemistry of Mineral Materials Laboratory, Faculty of Science, University of Yaounde $1-$ Cameroon. The heating rate is $10 \% \mathrm{~min}$. The flue gas is oxygen. The crucible is alumina oxide of capacity $150 \mathrm{mg}$; the loading mass is $100 \mathrm{mg}$; the initial heating temperature is $20^{\circ} \mathrm{C}$. We were given a thermogram TG coupled DSC with data records.

\section{5) Fourier transformed infrared analysis}

The FTIR analyses were carried out using the iS5 spectrometer. The spectra were acquired in the range of 4000 to $480 \mathrm{~cm}^{-1}$ at a resolution of $4 \mathrm{~cm}^{-1}$. Characteristic absorptions bands of the processed composites were registered.

\section{6) PVC}

The analyses performed on the hulls were also made on PVC under similar conditions.

7) PVC mixture with $12.54 \%$ of palm kernel shell powder before shaping.

According to literature, mixing powders (PVC + filler + additives) have to go through analysis before shaping [22] [23]. The most used analysis in companies is thermogravimetry and differential scanning calorimetry analysis in order to ensure a good mixing and success in the shaping of the load with the polymer (PVC) and its additives [2] [23] [24]. A dosage of 12.54\% load of kernel nut shell powder was chosen. This dosage is chosen because the calcium carbide feeds frequently used in companies in Cameroon do not exceed $20 \%$.

A mixture of $33.33 \mathrm{~kg}$ (81.17\%) of PVC, $1.30 \mathrm{~kg}(3.17 \%)$ of stabilizer, $0.70 \mathrm{~kg}$ (1.70\%) of lubricant, $0.48 \mathrm{~kg}(1.16 \%)$ of plasticizer, $0.09 \mathrm{~kg}(0.23 \%)$ of titanium dioxide, $0.01 \mathrm{~kg}(0.03 \%)$ of black charcoal, $5.15 \mathrm{~kg}(12.54 \%)$ of hull powder, corresponding total of $41.07 \mathrm{~kg}$ equivalent to $100 \%$ of mixture. The different percentages of the additives were chosen according to the standard applicable in the Cameroon company. The mixture is put in a mixer (steaming of the mixture) to make them perfectly homogeneous. A sample is taken and a thermogravimetric 
and differential scanning calorimetry analysis is done with the same apparatus as described before and under the same conditions.

Apart from the analyses of thermogravimetric and differential scanning calorimetry, all the manipulations were done 6 times and the means of the six tests were expressed with standard deviation.

\section{Results and Discussions}

\subsection{Transformation of Raw Palm Kernel Shell to Palm Kernel Powder}

The passage of palm kernel shell in a crusher-mill and then in an industrial micronizer helped to transform palm kernel shell of dura palm into palm kernel powder with a size smaller than $50 \mu \mathrm{m}$ [3] [6] [7]. After micronization, we sieved using a $50 \mu \mathrm{m}$ afnor sieve. Analysis of the obtained poweder after sieving, shown that nothing left in the sieve used. This allows confirming the particle size of 50 $\mu \mathrm{m}$ was obtained with the manufactured crusher-mill-micronizer. This may be comparable to the granulometry of the calcium carbide used as the filler in PVC.

\subsection{Apparent Density}

Density is an important parameter for plastic composite in view to obtained material that is less heavy. The average values obtained in the case of apparent density is: $\rho_{v}=0.680 \mp 0.013 \mathrm{~g} / \mathrm{cm}^{3}$. This proves that there is not enough vacuum between the powder seeds. This density can be compared to the density of plant fibers such as bagasse [25], oil palm empty fruit bunches [26] [27] [28]. The result can be comparable to those obtained by Ernesto de la Torre Chauvin [21].

\subsection{Wet Density}

The average values obtained in the case of wet density is: $\rho_{m}=0.505 \mp 0.006 \mathrm{~g} / \mathrm{cm}^{3}$. This result proves that the shell powder of dura is hydrophilic probably due the presence of hydroxyls group that can fix water molecules via the formation of hydrogen bounds. The real density $\rho_{r}$ of the palm kernel powder shell is between the two densities obtained $0.505 \leq \rho_{r} \leq 0.681 \mathrm{~g} / \mathrm{cm}^{3}$.

When measuring masses for mixing (steaming), the masses are measured poured into breasts. During shaping, the resin melts and the powder absorbs the resin to crystallize the materials. The results obtained, allow saying that the density of the kernel powder from Cameroon is between 0.505 and $0.680 \mathrm{~g} / \mathrm{cm}^{3}$. In literature, it is found that the density of some polymers is: 1.38 to 1.41 for PVC), 0.89 to 0.93 for PE, of 0.85 to 0.92 for PP and 1.12 to $1.16 \mathrm{~g} / \mathrm{cm}^{3}$ for Nylon 6.6. The values of the density of palm kernel powder obtained, compared to the density values of some plant fibers used to reinforced polymers such as hemp $\left(1.5 \mathrm{~g} / \mathrm{cm}^{3}\right)$, feather $\left(0.9 \mathrm{~g} / \mathrm{cm}^{3}\right)$, Wool $\left(1.3 \mathrm{~g} / \mathrm{cm}^{3}\right)$, sisal $\left(1.3-1.5 \mathrm{~g} / \mathrm{cm}^{3}\right)[12]$, show that the plastic obtained after processing will be very light. This offers a very great advantage to palm kernel powder as filler for polymers, especially with 
a high loading percentage, now that the automotive and aeronautics sectors are making the construction lighter to limit greenhouse gas emissions.

On the other hand, the hydrophobic behavior of the shell powder remains unchanged after shaping. As a result, the rate of absorption and desorption of fluids is washed away [6]. Vegetable materials are degradable. These results show that the degradation of the plastic obtained will be accelerated at a high load rate. These phenomena make it possible to look at palm kernel husk powder as filler for polymers.

\subsection{Moisture Content of Shell Powder}

The means value obtained from these results showed the moisture content of palm kernel powder is $1.6 \% \pm 0.1 \%$. From this moisture content value, it appears that the shell powder does not have enough water for hydration and that this measurement was made when the powder had just been dried to be ground. It will not be doubtful to find such a high humidity level, as the result brought by Ernesto de la torrechauvin in his thesis [21]. Comparing the result obtained with the result obtained by Ernesto de la torrechauvin it can be concluded that, the palm kernel powder was taken well dried.

\subsection{Infrared Fourier Transform Analyses}

On Figure 3 below, we presented the infrared of raw palm kernel powder, raw PVC and of composite (PVC $+12.5 \%$ of palm kernel powder).

In Figure 3, FT-IR analysis of raw palm oil kernel shell shows different peak intensities. The large peak intensity at $3363 \mathrm{~cm}^{-1}$ can be attributed to $\mathrm{O}-\mathrm{H}$ stretching group of alcohols (cellulose content in raw palm oil kernel shell). The intensity at $2950 \mathrm{~cm}^{-1}$ can be attributed to C-H stretching group of alkanes or the vibrations of the methoxy group of lignin. The intensity peak between 1718 $1700 \mathrm{~cm}^{-1}$ can be attributed to $\mathrm{C}=\mathrm{O}$ stretching, or to $\mathrm{C}-\mathrm{C}$ stretching of aromatic

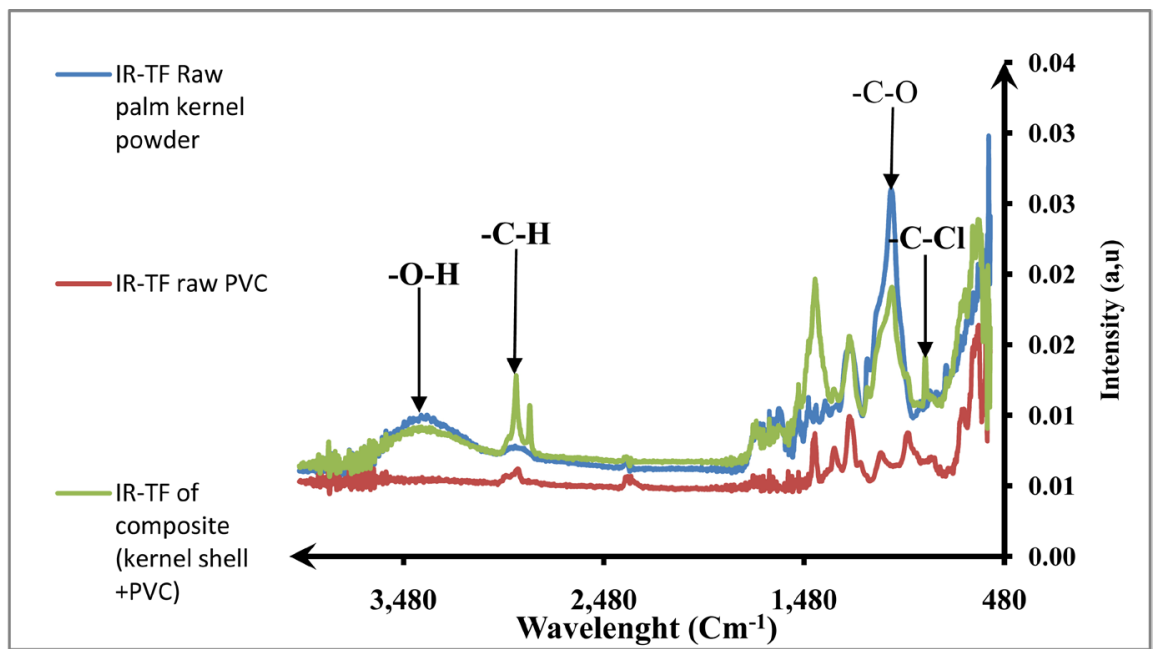

Figure 3. Infrared of raw palm kernel powder, raw PVC and composite (PVC $+12.5 \%$ of palm kernel powder). 
ring or carboxyl group of lignin. The peak between $1300-1000 \mathrm{~cm}^{-1}$ and those of 1243 - $1044 \mathrm{~cm}^{-1}$ could be attributed to C-O stretch of alcohols, esters or ethers. These results are in agreement with data found in literature concerning palm kernel shell. Kundu et al. 2015 [12], Hidayu et al. 2013 [2] obtained the same shape and result during the studies of palm oil kernel to produced activate carbon.

The FT-IR analysis of polyvinyl chloride shows peak intensities at 2909, 1425, $1325,1253,1095,962,825$ and $607 \mathrm{~cm}^{-1}$. The peak intensity at $2909 \mathrm{~cm}^{-1}$ can be attributed to the vibration of $\mathrm{C}-\mathrm{H}$. The intensity at $1425 \mathrm{~cm}^{-1}$ can be attributed to $-\mathrm{C}-\mathrm{H}$ deformation. The intensity at $1325 \mathrm{~cm}^{-1}$ can be attributed to $-\mathrm{CH}_{2}$ deformation. The intensity at $1253 \mathrm{~cm}^{-1}$ can be attributed to $-\mathrm{C}-\mathrm{H}$ rocking mode or out of plane angular deformation of $-\mathrm{C}-\mathrm{H}$. The intensity at $962 \mathrm{~cm}^{-1}$ can be attributed to trans -C-H wagging mode or out of plane trans deformation. The intensity at $825 \mathrm{~cm}^{-1}$ can be attributed to $-\mathrm{C}-\mathrm{Cl}$ bond stretching. The intensity at $607 \mathrm{~cm}^{-1}$ can be attributed to $-\mathrm{CH}$ cis wagging mode. These peak intensities are in accordance with data found in literature concerning PVC [2] [4] [16] [29].

The FT-IR analysis of polyvinyl chloride with 12.54 palm oil kernel mixture shows different intensities peak. The peak intensity at $3301.52 \mathrm{~cm}^{-1}$ can be attributed to the vibration of $-\mathrm{O}-\mathrm{H}$. The intensity at 2917.02 and $2849.13 \mathrm{~cm}^{-1}$ can be attributed to $-\mathrm{C}-\mathrm{H}$. The intensity at $1424.71 \mathrm{~cm}^{-1}$ can be attributed to $-\mathrm{C}-\mathrm{H}$ rocking mode or out of plane angular deformation of $-\mathrm{C}-\mathrm{H}$. The intensity at $1424.71 \mathrm{~cm}^{-1}$ can be attributed to trans $-\mathrm{C}-\mathrm{H}$ wagging mode or out of plane trans deformation. The intensity at $1041.05 \mathrm{~cm}^{-1}$ can be attributed to $-\mathrm{C}-\mathrm{O}$. The intensity at $874.56 \mathrm{~cm}^{-1}$ can be attributed to $\mathrm{C}-\mathrm{Cl}$. We can note a decrease in intensity at $3301 \mathrm{~cm}^{-1}$ of the $-\mathrm{O}-\mathrm{H}$ groups of the palm oil kernel which can means that there is a new bond that was create between the PVC and palm oil kernel. The same observation was done at $1041 \mathrm{~cm}^{-1}$ with the increasing intensity compared to PVC and decreased compared to palm oil kernel. At 2917, 1424, 1253, we observe a strong increase of intensity of the groupings. All these increases, decreases and creations of grouping may imply an interaction between palm kernel nuts powder with PVC [2] [24].

\subsection{Thermogravimetric and Differential Scanning Calorimetry}

In Figure 4, we present the thermogravimetric and differential scanning calorimetry of raw kernel nut shell powder.

Figure 4 shows the mass loss (TG) (in red) and the differential scanning calorimetry (DSC) in blue of the raw kernel nut, for a temperature velocity of $10^{\circ} \mathrm{C} / \mathrm{min}$ at atmosphere controlled by oxygen.

In this figure, it appears that the raw material exhibits three degradation phases:

1) Dehydration: the degradation starts at $101^{\circ} \mathrm{C}$ and leads to about $1.13 \%$ of mass loss. This phase corresponds to linked water evaporating from the material [6] [7]. 


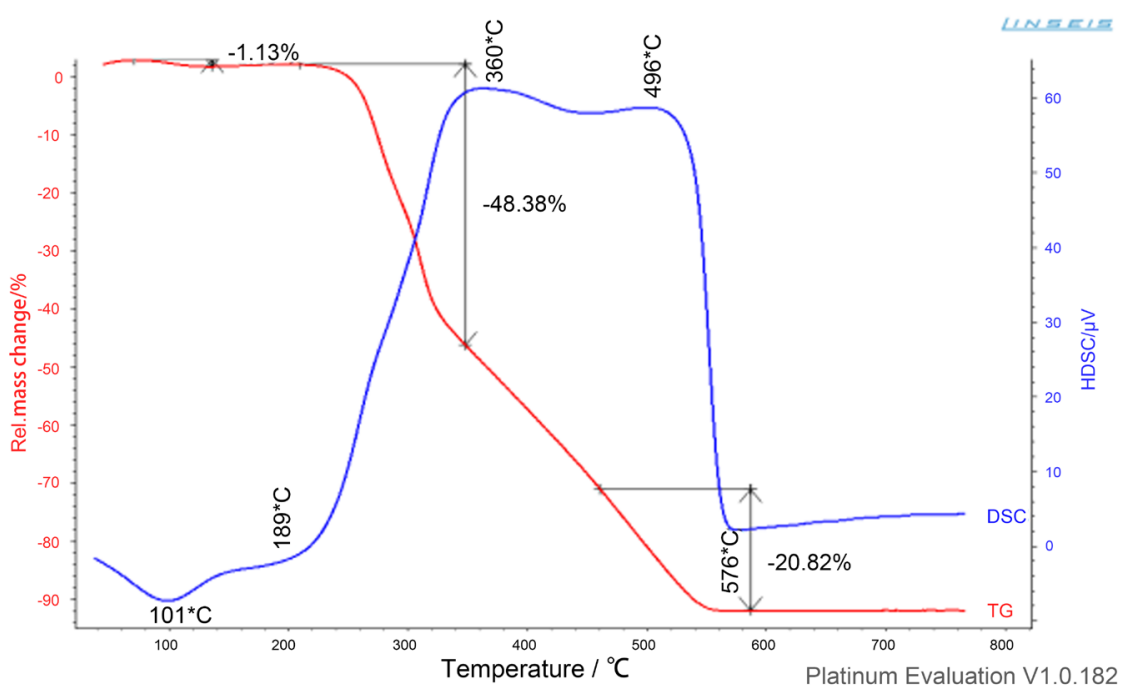

Figure 4. Thermogravimetric and differential scanning calorimetry of raw palm kernel shell powder.

2) Hemicellulose and Cellulose degradation: the degradation starts at $189^{\circ} \mathrm{C}$, end around $380^{\circ} \mathrm{C}$ and lead to about $48.38 \%$ of mass loss. In this phase hemicellulose decompose between $189^{\circ} \mathrm{C}$ and $300^{\circ} \mathrm{C}$, the cellulose decompose between $300^{\circ} \mathrm{C}$ and $380^{\circ} \mathrm{C}$. When the two polymers are degraded, the material re-equilibrates by forming others phases and releasing a calcinate.

3) Lignin degradation: the degradation starts around $400^{\circ} \mathrm{C}$ and leads to about $20.82 \%$ of mass loss. The entire bonds are broken, a large part of the material is pyrolyzed and only the ashes remain.

These results are in agreements with the results obtained by others researchers [24].

The DSC shows an endothermic peak of heat at $101^{\circ} \mathrm{C}$. During the degradation of cellulose and hemicelluloses, DSC presents a peak at $360^{\circ} \mathrm{C}$ and during the degradation of lignin there is another peak at $496^{\circ} \mathrm{C}$. It can be also note that the ignition temperature is $200^{\circ} \mathrm{C}$ and the burnout temperature is $580^{\circ} \mathrm{C}$ for the raw palm kernel shell.

As the aim of this work is to use the palm kernel shell as filler, it is necessary to study the behavior of palm kernel shell between 0 and $250^{\circ} \mathrm{C}$. The ideal processing temperatures of several polymers are between $80^{\circ} \mathrm{C}$ for polyethylene and $250^{\circ} \mathrm{C}$ for polytetrafluoroethylene or between $170^{\circ} \mathrm{C}$ and $205^{\circ} \mathrm{C}$ for rigid PVC that we studied [2]. These analyses are made in order to understand the phenomenon of polymer degradation (PVC) and that of the loads (palm kernel shell) in the interval frames of the development of plastic (between $80^{\circ} \mathrm{C}$ and $250^{\circ} \mathrm{C}$ ). Subsequently, the behavior of the polymer blend powder (PVC) (with its shaping additives) is studied as well the load of well-cured palm kernel husk powder to understand the state of the plastic material obtained with this mixture. Finally, they were tried to understand the behavior of the plastic material resulting from this mixing powder in its total degradation by studying the beha- 
vior of the polymer (PVC) on one hand and the shell powder on the other under hand in the same conditions.

The Figure 5(a) \& Figure 5(b) below, present the thermogravimetric and differential scanning calorimetry of raw palm kernel shell between $0{ }^{\circ} \mathrm{C}$ and $250^{\circ} \mathrm{C}$.

Figure 5 tells us about the thermal behavior on the total degradation of palm kernel shell powder between $0^{\circ} \mathrm{C}$ and $250^{\circ} \mathrm{C}$. Literature says that most polymers have their shaping temperature below $250^{\circ} \mathrm{C}$. From the Figure 5(a), it appears that the water starts to evaporate around $70^{\circ} \mathrm{C}$, this could be attributed at free water. After the departure of water, around $189^{\circ} \mathrm{C}$ the constituents of raw material begin to degrade. This temperature corresponds to degradation of hemicelluloses polymer. At this temperature, cellulose and lignin are not degraded. At this temperature, several polymers have already exceeded their processing temperature. Thus, cellulose and lignin shell still have all their properties to offer to the plastic (PVC) all the possibilities to have good resistance.

Similarly, Figure 5(b) shows that in its degradation process in the temperature range that surrounds the shaping temperature of the polymers. It can be observed that outside free water at $101^{\circ} \mathrm{C}$ the palm kernel shell still retain their structure at more than $80 \%$ of their initial mass. Hemicellulose is infinitely small (TG), cellulose begins to absorb heat to enter total degradation $\left(360^{\circ} \mathrm{C}\right)$. This justifies that the shell powder still keeps the maximum of its crystalline and chemical structure. Then a mixture of polymer with palm kernel powder will bring a very good improvement of several properties of the polymer.

\subsection{Results of PVC}

\section{Characteristic parameters:}

The PVC used for this study comes from DANSUK INDUSTRY4. It was delivered to us in a $25 \mathrm{~kg}$ bag in the form of a white powder ( $\mathrm{KN} \mathrm{500).}$

The TG and DSC of raw PVC are presented in Figure 6.

Figure 6 shows the mass loss (TG) (in red) and the differential scanning calorimetry (DSC) in blue of the raw PVC, for a temperature velocity of $10^{\circ} \mathrm{C} / \mathrm{min}$ at atmosphere controlled by oxygen. In this figure, it appears that there are

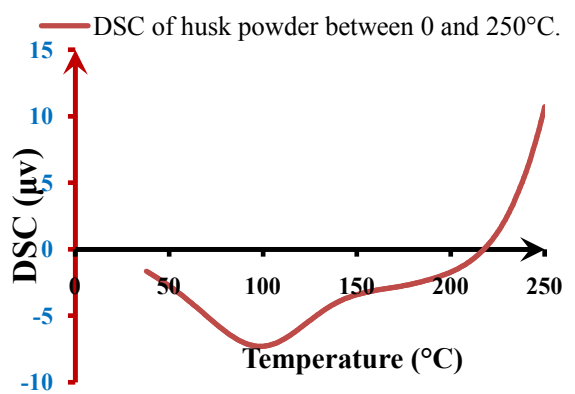

(a)

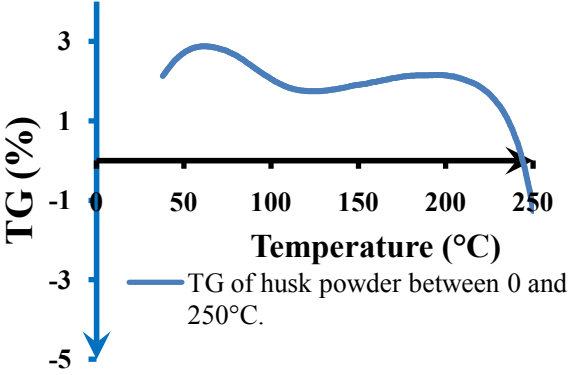

(b)

Figure 5. Thermogravimetric (a) and differential scanning calorimetry (b) of raw palm kernel shell between $0^{\circ} \mathrm{C}$ and $250^{\circ} \mathrm{C}$. 


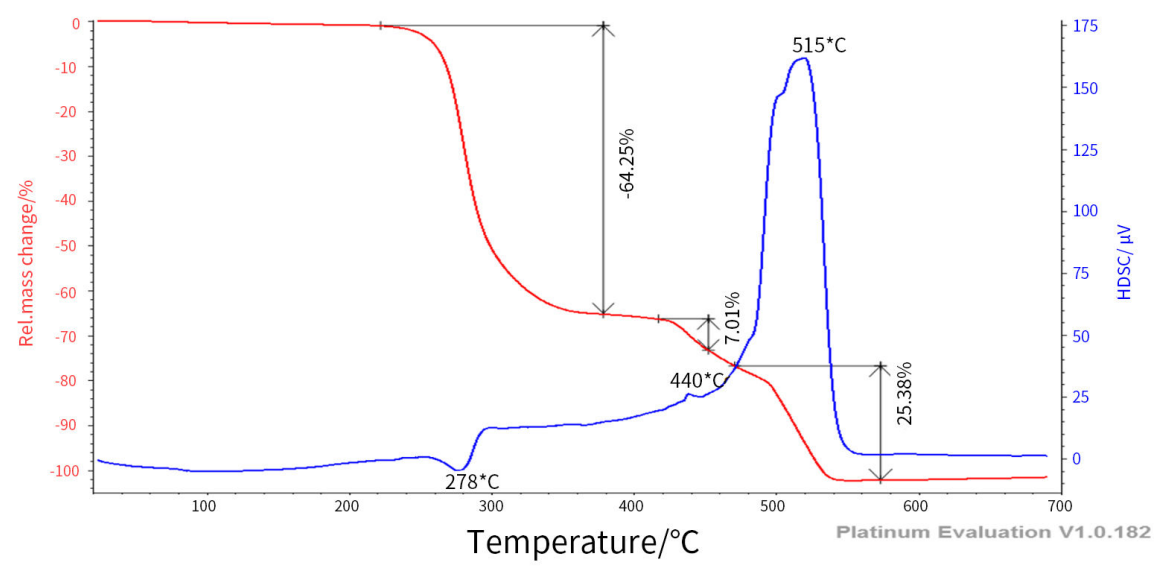

Figure 6. Thermogravimetric and differential scanning calorimetry of raw PVC.

three main phases of degradation of the raw PVC:

1) Dechlorination phase: the degradation starts at $220^{\circ} \mathrm{C}$ and leads to about $64.25 \%$ of mass loss. This phase corresponds to the degradation of $\mathrm{HCl}$ and the formation of polyene structure.

2) Condensation phase: this phase starts at $420^{\circ} \mathrm{C}$ and end at $470^{\circ} \mathrm{C}$ and leads to about $7.01 \%$ of weight loss. In this phase, a part of polyene is degraded and the other part of the polyene molecules rearrange through cyclization reactions and crosslinking by forming aromatic hydrocarbons and ashes.

3) Fragmentation phase: this phase starts at $470^{\circ} \mathrm{C}$ and leads to about $25.38 \%$ of weight loss. The aromatic compounds formed before are degraded, all the material being degraded, only the ashes remain.

These results are in agreements with the results obtained by others researchers [4] [30].

The DSC shows an endothermic peak of heat at $278^{\circ} \mathrm{C}$. During the degradation of polyene and aromatic compounds an exothermic is observed at $440^{\circ} \mathrm{C}$ and $515^{\circ} \mathrm{C}$. It can also be noted that the ignition and the burnout temperatures for the raw $\mathrm{PVC}$ are around $220^{\circ} \mathrm{C} 560^{\circ} \mathrm{C}$ respectively.

The DSC of PVC was also done in order to determine the glass transition temperature (Tg). This is an important parameter for polymer characterization because it permits to evaluate the plasticizing effects of substances when it is added on polymers. The curve of the DSC of PVC is presented in Figure 7 in the range between $0^{\circ} \mathrm{C}$ to $250^{\circ} \mathrm{C}$.

As we can observe in Figure 7, we an endothermic peak between the ranges of the temperature chosen. From this curve, it appears that the glass transition temperature of pure $\mathrm{PVC}$ is $98.56^{\circ} \mathrm{C}$ which is in the glass transition temperature range found in literature for this polymer [4] and the melting temperature is $147.84^{\circ} \mathrm{C}[30]$.

\subsection{Results of the PVC Blending Powder and 12. 54\% of the Palm Kernel Shell Powder}

After the study of raw palm kernel shell and PVC, we made a composite loaded 


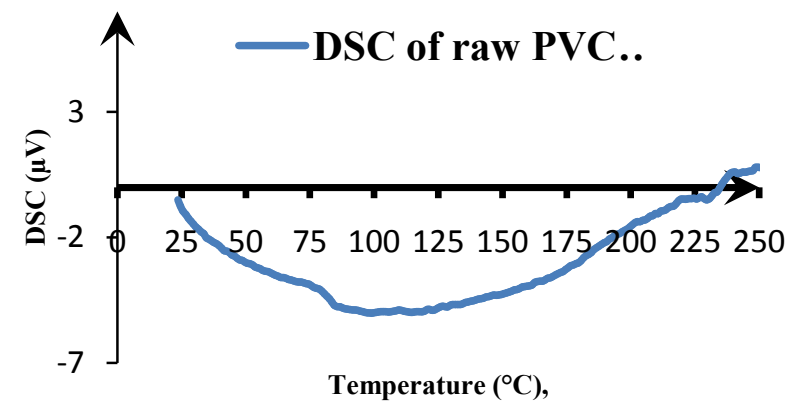

Figure 7. Differential scanning calorimetry of raw PVC at the temperature between $0^{\circ} \mathrm{C}$ to $250^{\circ} \mathrm{C}$.

at $12.54 \%$ with palm kernel shell. The Figure 8 presents the thermogravimetric and Differential scanning calorimetry of the composite.

The Figure 8 is the TG in red and DSC in blue of the composite (PVC + $12.54 \%$ of the palm kernel powder). The TG shows that there are three peaks of the thermal degradation of the composite:

1) Dehydration: the degradation starts at $98^{\circ} \mathrm{C}$ and leads to about $1.02 \%$ of mass loss. This phase corresponds to the dehydration of the material.

2) The second phase of degradation starts around $235^{\circ} \mathrm{C}$ and end around $360^{\circ} \mathrm{C}$, consist of the dechlorination of PVC, the degradation of cellulose and hemicelluloses structures. This phenomena leads to a mass loss of $64.21 \%$. In this phase there is also a rearrangement of the composite and production of the ashes. Compared with the TG of palm kernel shell and PVC at $360^{\circ} \mathrm{C}$, there is a decrease in mass equivalent to $64.21 \%$ of the dry mass against $64.25 \%$ for PVC and $48.48 \%$ for palm kernel shell. This influence is weak because the loading rate of the palm kernel shell powder is low, hence the behavior of the TG tend towards the TG of PVC.

3) The third phase of degradation starts at $360^{\circ} \mathrm{C}$ and leads to $20.82 \%$ of weight losses. This phase consist of degradation of lignin and residual residue and the production of ashes that shows the total combustion of the composite. We can also note that the ignition temperature is around $98^{\circ} \mathrm{C}$ and the burnout temperature is $540^{\circ} \mathrm{C}$ for the composite.

The DSC curves (Figure 8) shows an endothermicpeak between $90^{\circ} \mathrm{C}$ and $95^{\circ} \mathrm{C}$ corresponding to the glass transition phase of the composite. We note from the DSC that the glass transition temperature is $95^{\circ} \mathrm{C}$ against $98.65^{\circ} \mathrm{C}$ for PVC. After this temperature, the heat evolution flux is progressive up to its crystallization start temperature which is about $391^{\circ} \mathrm{C}$. Similarly, the mixture enters total crystallization where it peaks at $459^{\circ} \mathrm{C}$. The residue is deposited at the bottom of the crucible and absorbs heat near $478^{\circ} \mathrm{C}$ where it crystallizes for the second time leaving the ash at $556^{\circ} \mathrm{C}$. Surely, the residues come from the mixture of shell powder and PVC that have been calcined.

By comparing the different DSC, it can be observed that palm kernel powder absorbs more heat than PVC. This phenomenon can be justified by heat absorption 


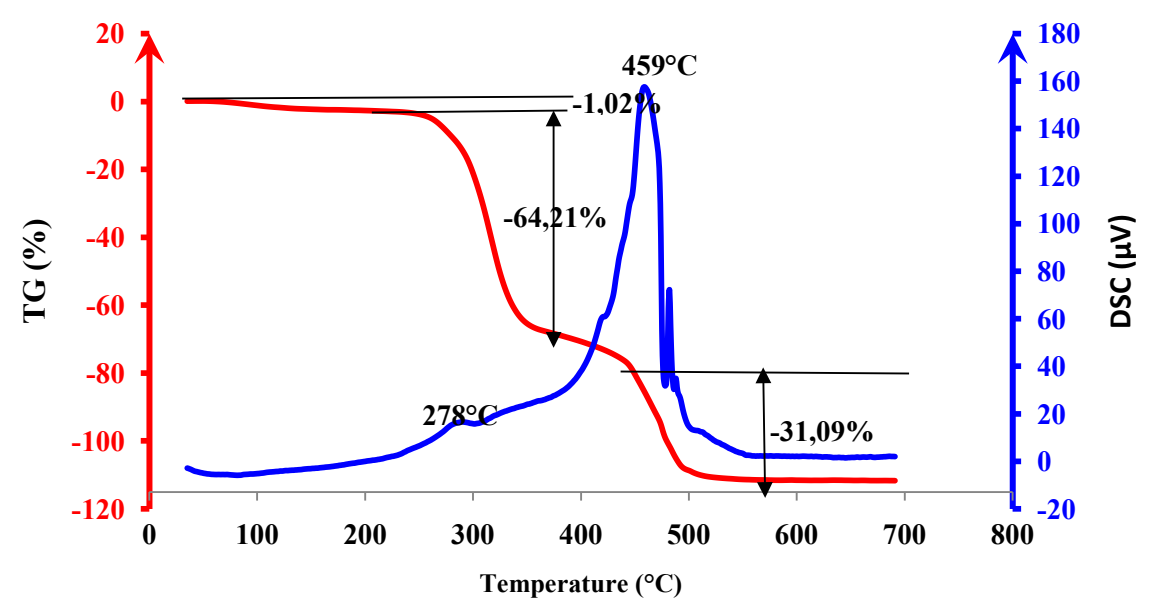

Figure 8. Thermogravimetric and Differential scanning calorimetry of the composite.

of carbon [6] [21] contained in the powder. This parameter allows therefore, taking precautions in the setting of the temperature $\left(170^{\circ} \mathrm{C}\right.$ to $205^{\circ} \mathrm{C}$ for $\left.\mathrm{PVC}\right)$ of the machine at the time of shaping the PVC mixture loaded with palm kernel shell powder. This heat absorption of the powder influence the parameters such as the glass transition temperature $\left(95^{\circ} \mathrm{C}\right)$, the melting temperature $\left(149^{\circ} \mathrm{C}\right)$, the start temperature of crystallization $\left(409^{\circ} \mathrm{C}\right)$, the peak temperature of crystallization $\left(459^{\circ} \mathrm{C}\right)$ of the elaborated plastic material [2] [24].

One of the important parameters of a material is its degradation as a function of the increase or decrease of the temperature. After the study of the TG and DSC of palm kernel shell, PVC and composite, Hence, the next and important stage, was to see how the material absorbs heat during the weight loss. The result is presented in Figure 9.

From the Figure 9, it can be note that, the shell powder absorbs heat very quickly with a mass loss around $40 \%$ then, conserves this heat until its total degradation. This quickly absorption of heat can be attributed to the cellulose and hemicelluloses content in palm kernel powder. On the other hand, PVC slowly absorbs the heat but quickly loss mass when is hot up to about $75 \%$. Between these two behaviors described, the composite obtained presented an intermediate behavior. The composite obtained absorbs moderately heat and have a mass loss around $60 \%$ and enters crystallization zone. Following these findings, one can say that palm kernel powder greatly influences the plastic material especially if it is used at a high percentage. This phenomenon of the conservation of the heat by a material offers an advantage to the palm kernel shell powder today if it is used as load during the fabrication of clothes for winter, for sailors especially for the regions where cold predominates. It can also be used as a coating (paint) for the hot storage of products to name just these examples.

In Table 2, we presented the different temperature obtained.

Table 2 shows that the glass transition temperature went from $98.56^{\circ} \mathrm{C}$ for $\mathrm{PVC}$ to $95^{\circ} \mathrm{C}$ for the composite which brings the melting temperature to $147.78^{\circ} \mathrm{C}$ for PVC to $142.5^{\circ} \mathrm{C}$ for the composite. It is thus noted that there has 
Table 2. Impact of palm kernel powder on the phase change temperatures.

\begin{tabular}{cccccc}
\hline & $\begin{array}{c}\text { Glass transition } \\
\text { temperature }(\mathrm{Tg})\end{array}$ & $\begin{array}{c}\text { Melting } \\
\text { temperature } \\
(\mathrm{Tm})\end{array}$ & $\begin{array}{c}\text { Crystallization } \\
\text { start temperature } \\
(\mathrm{Tec})\end{array}$ & $\begin{array}{c}\text { Peak } \\
\text { crystallization } \\
\text { temperature }(\mathrm{Tc})\end{array}$ & $\begin{array}{c}\text { Ashes start } \\
\text { temperature } \\
(\mathrm{Ta})\end{array}$ \\
\hline $\mathrm{PVC}$ & $98.56^{\circ} \mathrm{C}$ & $147.84^{\circ} \mathrm{C}$ & $455.56^{\circ} \mathrm{C}$ & $519.5^{\circ} \mathrm{C}$ & $556^{\circ} \mathrm{C}$ \\
Composite & $95^{\circ} \mathrm{C}$ & $142.5^{\circ} \mathrm{C}$ & $368^{\circ} \mathrm{C}$ & $459^{\circ} \mathrm{C}$ & $558^{\circ} \mathrm{C}$ \\
\hline
\end{tabular}

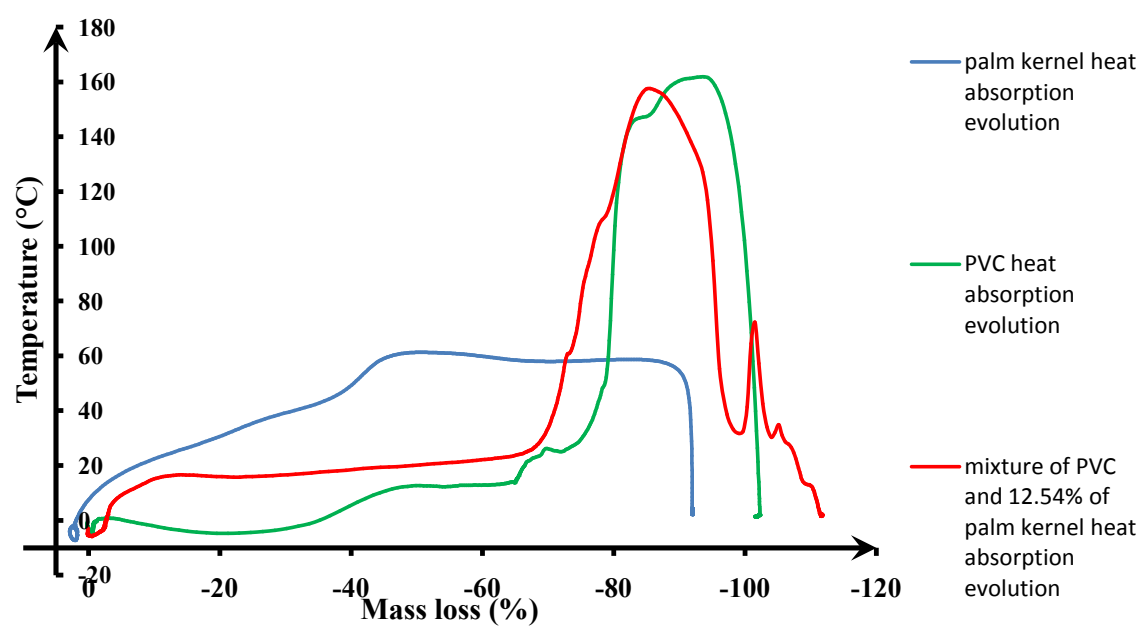

Figure 9. Absorption of heat during the mass loss of different materials.

been a decrease in the glass transition temperature of PVC. It can thus be concluded that the palm kernel shell reinforces the plasticizing effect like all natural plasticizers. Then, we obtained the crystallization start temperature at $455^{\circ} \mathrm{C}$ for the PVC against $368^{\circ} \mathrm{C}$ for the composite, which gives the crystallization peak temperature of $519^{\circ} \mathrm{C}$ for the PVC against $495^{\circ} \mathrm{C}$ for the composite. Finally the ash is started to be obtained around $556.56^{\circ} \mathrm{C}$ for the PVC against $558^{\circ} \mathrm{C}$ for the composite.

\section{Conclusion}

In this study we transformed palm kernel shell to palm kernel powder. We have studied the possibility of using palm kernel powder as filler for polymers and using PVC as polymer. The results show us that the load of palm kernel shell powder greatly reduces the phase temperatures of the polymers. In the same way, the palm kernel shell load decreases the mass loss of the PVC loaded up to the melting point of the PVC, but in the crystallization phase of PVC, the loss of mass decreases to its degradation. From the thermogravimetric curve of palm kernel shell, we observed three levels of degradation of raw matter with $1.13 \%$, $48.38 \%$ and $20.82 \%$ of weight loss respectively. These different mass losses have attributed to the dehydration (1.13\%), hemicelluloses and cellulose (48.38\%) and lignin (20.82\%). The composite made by filler PVC with $12.5 \%$ of palm kernel shell permits us to conclude that, the behavior of composite is between the behavior of PVC and palm kernel shell powder. The diminution of glass transition 
temperature ensures us that we can use the palm kernel shell powder to produce new material with news performances.

\section{References}

[1] Abdul Khalil, H.P.S., Tehrani, M.A., Davoudpour Y., Bhat A.H., Jawaid M. and Hassan, A. (2013) Natural Fiber Reinforced poly (vinyl chloride) Composites: A Review. Journal of Reinforced Plastics and Composites, 32, 330-356. https://doi.org/10.1177/0731684412458553

[2] Hidayu, A.R., Mohamad, N.F., Matali, S. and Sharifah, A.S.A.K. (2013) Characterization of Activated Carbon Prepared from Oil Palm Empty Fruit Bunch Using BET and FT-IR Techniques. Procedia Engineering, 68, 379-384. https://doi.org/10.1016/j.proeng.2013.12.195

[3] Chul Seoung, B., Kye Hong, C. and Ji-Whan, A. (2014) Effect of Grain Size and Replacement Ratio on the Plastic Properties of Precipitated Calcium Carbonate Using Limestone as Raw Material. Journal of the Korean Ceramic Society, 51, 127-131. https://doi.org/10.4191/kcers.2014.51.2.127

[4] González, N. and Fernandez-Berridi, M.J. (2006) Application of Fourier Transform Infrared Spectroscopy in the Study of Interactions between PVC and Plasticizers: PVC/Plasticizer Compatibility versus Chemical Structure of Plasticizer. Journal of Applied Polymer Science, 101, 1731-1737. https://doi.org/10.1002/app.23381

[5] Malkapuram, R., Kumar, V. and Singh Negi, Y. (2009) Recent Development in Natural Fiber Reinforced Polypropylene Composites. Journal of Reinforced Plastics and Composites, 28, 1169-1189. https://doi.org/10.1177/0731684407087759

[6] Dulebová, L. and Moravskyi, V. (2015) Evaluation of Properties of Injected Polymer Composite Filled with Talc Mineral Filler. Transfer inovácií, 32.

[7] Turku, I., Karki, T. and Puurtinen, A. (2018) Durability of Wood Plastic Composites Manufactured from Recycled Plastic. Heliyon, 2018, e00559.

https://doi.org/10.1016/j.heliyon.2018.e00559

[8] Hajji, P., Marchand, F. and Pirri, R. (2008) Wood-PVC Composites: Formulation Optimization. Plastics, Rubber and Composites, 37, 388-391.

https://doi.org/10.1179/174328908X356527

[9] Abdeldjalil, S. and Nabil, R. (2013) Comportement au choc des stratifiées composites renforcées par des fibres naturelles (Fibre de Cactus). Université Kasdi Marbah Ouargla, $53 \mathrm{p}$.

[10] Abu-Sharkh, B.F. and Hamid, H. (2003) Degradation Study of Date Palm Fibre/Polypropylene Composites in Natural and Artificial Weathering: Mechanical and Thermal Analysis. Polymer Degradation and Stability, 85, 967-973. https://doi.org/10.1016/j.polymdegradstab.2003.10.022

[11] Koronis, G. and Silva, A. (2018) Green Composites Reinforced with Plant-Based Fabrics: Cost and Eco-Impact Assessment. Journal of Composites Science, 2, 18-21. https://doi.org/10.3390/jcs2010008

[12] Dong, C. (2018) Review of Natural Fibre-Reinforced Hybrid Composites. Journal of Reinforced Plastics and Composites, 35, 331-348. https://doi.org/10.1177/0731684417745368

[13] Khan, T., Hameed Sultan, M.T.B. and Hamdan Ariffin, A. (2018) The Challenges of Natural Fiber in Manufacturing, Material Selection, and Technology Application: A Review. Journal of Reinforced Plastics and Composites, 1-10. https://doi.org/10.1177/0731684418756762 
[14] Aboubakar, H.I. (2013) Analyse socio-économique de la filière artisanale d'huile de palme dans La région de la Sanaga-Maritime (Cameroun). Université Montpellier 3, $201387 p$.

[15] Droulers, M., Venturieri, A., Mourão, M., Thalês, M. and Poccard, R. (2011) Le palmier à huile: un avenir pour l'Amazonie? Confins 10/2010, mis en ligne le 28 mars 2011. http://journals.openedition.org/confins/6867

[16] Kundu, A., Sen Gupta, B., Hashim, M.A., Sahu, J.N., Mujawar, M. and Redzwan, G. (2015) Optimisation of the Process Variables in Production of Activated Carbon by Microwave Heating. RSC Advances, 5, 35899-35908. https://doi.org/10.1039/C4RA16900J

[17] Yombouno A. (2014) Grain: Historique de l'exploitation du palmier à huile en Afrique; planète.

[18] Epesse, M.S., Obounou, M., Ayina, O.L.M. and Caillat, S. (2013) Utilisation des coques de noix de palmiste comme combustible dans un four de fusion de la ferraille.Revue des Energies Renouvelables, 16, 75-89.

[19] Dietsch, P., Franke, S., Franke B., Gamper, A. and Stefan, W. (2014) Methods to Determine Wood Moisture Content and Their Applicability in Monitoring Concepts. Journal of Civil Structural Health Monitoring, 5, 115-127. https://doi.org/10.1007/s13349-014-0082-7

[20] Dansuk Industrial Ltd. CO. IndustralComplex'HEAD OFFICE: 705, 1DA-SHIHWA.

[21] Ernesto de la Torre, C. (2015) Préparation de charbon actif à partir de coques de noix de palmier à huile pour la récupération d'or et le traitement d'effluents cyanurés. Thèse, Université catholique de Louvain, $350 \mathrm{p}$.

[22] Trotignon, J.P., Verdu, J., Dobraczynski, A. and Piperaud, M. (2006) Matières plastiques. Structures propriétés, mise en oeuvre, normalisation. Nathan 2 éd, 231 p.

[23] Da Silva, M.A., Adeodato Vieira, M.G., Gomes Maçumoto, A.C. and Masumi Beppu, M. (2011) Polyvinylchloride (PVC) and Natural Rubber Films Plasticized with a Natural Polymeric Plasticizer Obtained through Polyesterification of Rice Fatty Acid. Polymer Testing, 30, 478-484. https://doi.org/10.1016/j.polymertesting.2011.03.008

[24] Yang, H., Yan, R., Chen, H., Lee, D.H. and Zheng, C. (2007) Characteristics of Hemicellulose, Cellulose and Lignin Pyrolysis. Fuel, 86, 1781-1788. https://doi.org/10.1016/j.fuel.2006.12.013

[25] Anarghya, A., Vijaykumar, G., Manikandan, I. and Narendra, R. (2017) A Review of Fibrous Reinforcements of Concrete. Journal of Reinforced Plastics and Composites, 36, 519-552. https://doi.org/10.1177/0731684416685168

[26] Jawaid, M., Abdul Khalil, H.P.S. and Abu Bakar, A. (2010) Mechanical Performance of Oil Palm Empty Fruit Bunches/Jute Fibres Reinforcedepoxy Hybrid Composites. Materials Science and Engineering A, 527, 7944-7949. https://doi.org/10.1016/j.msea.2010.09.005

[27] Jawaid, M., Abdul Khalil, H.P.S., Abu Bakar, A. and Noorunnisa Khanam, P. (2011) Chemical Resistance, Void Content and Tensile Properties of Oil Palm/Jute Fibre Reinforced Polymer Hybrid Composites. Materials and Design, 32, 1014-1019. https://doi.org/10.1016/j.matdes.2010.07.033

[28] Jawaid, M., Abdul Khalil, H.P.S. and Abu Bakar, A. (2011) Woven Hybrid Composites: Tensile and Flexural Properties of Oil Palm-Woven Jute Fibres Based Epoxy Composites. Materials Science and Engineering A, 528, 5190-5195. https://doi.org/10.1016/j.msea.2011.03.047

[29] Alghunaim, N.S. (2015) Spectroscopic Analysis of PMMA/PVC Blends Containing 
$\mathrm{CoCl}_{2}$. Results in Physics, 5, 331-336. https://doi.org/10.1016/j.rinp.2015.11.003

[30] Radhakrishnan Nair, M.N., Thomas George, V. and Gopinathan Nair, M.R. (2007) Thermogravimetric Analysis of PVC/ELNR Blends. Polymer Degradation and Stability, 92, 189-196. https://doi.org/10.1016/j.polymdegradstab.2006.11.014 